\title{
GRAIN SORGHUM PRODUCTIVITY IN SANDY CALCAREOUS SOIL UNDER MODERN IRRIGATION SYSTEMS USING DIFFERENT LEVELS OF FARMYARD MANURE AND MINERAL NITROGEN FERTILIZER \\ Ali, E.A \\ Agron. Dept., Fac. of Agric., Assiut Univ., Egypt.
}

\section{ABSTRACT}

This work was carried out at El-Wadi El-Assiuty farm, faculty of Agriculture, Assiut University,Egypte in 2003 and 2004 seasons to study the response of two grain sorghum genotypes (Dorado and Shandawil 6) to new systems of irrigation (drip and sprinkler) and farmyard-mineral fertilizer in sandy calcareous soil. Each season contain two experiments. One experiment subjected to Drip irrigation and the other to Sprinkler one. Each experiment contained two variables in split plot design with three replications. The grain sorghum genotypes were assigned to main plots. The subplots were allocated to the farmyard-mineral fertilizer ( 0.0 ton farmayard manure + $190 \mathrm{~kg} \mathrm{~N}, 1.5$ ton farmyard manure $+160 \mathrm{~kg} \mathrm{~N}, 3.0$ ton farmyard manure $+130 \mathrm{kgN}$, 4.5 ton farmyard manure $+100 \mathrm{kgN}, 6.0$ ton farmyard manure $+70 \mathrm{~kg} \mathrm{~N}$ and 7.5 ton farmyard manure $+40 \mathrm{~kg} \mathrm{~N} / \mathrm{ha}$ ). The obtained results indicated that drip irrigation system surpassed sprinkler one in plant height $(\mathrm{cm})$, panicle length and width $(\mathrm{cm})$, panicle weight $(\mathrm{g})$, grain yield per plant $(\mathrm{g}), 1000$-grain weight $(\mathrm{g})$ as well as grain yield in $\mathrm{kg} / \mathrm{ha}$ and water use efficiency $\left(\mathrm{kg} / \mathrm{m}^{3}\right)$. Otherwise, grain protein content was significantly decreased with drip irrigation system. Shandawil 6 genotype gained the highest values of all tested traits except grain protein content when compared with dorado one. F6 treatment of farmyard manure exhibited a highly significant effect in all studied traits in the two growing seasons. The second order interaction of farmyard manure $\mathrm{x}$ irrigation system $\mathrm{x}$ genotypes had a significant effect on plant height, 100grain weight, grain yield/plant and grain yield /ha The highest values of previous traits were gained when Shandawil 6 genotype was sowed under drip irrigation system and fertilized with $f 6$ fertilizer treatment in both seasons.

Keywords: Sorghum, genotypes, drip and sprinkler irrigation, farmyard manure, sandy calcareous soil

\section{INTRODUCTION}

In Egypt, the cultivated area of grain sorghum (Sorghum bicolor L.) in the Nile Valley and Delta is limited due to the competition with the other important summer crops. However, it could be cultivated in the newly reclaimed soil in the desert area. The cultivation of the new reclaimed sandy soils in Egypt depends upon the irrigation system and soil fertility which controlled the crops productivity. There is a need to develop a system using new systems of irrigation and using natural organic fertilizer such as farmyard manure. Many investigations in this respect on different crops were recorded by (Osman, 2001 and Ali, 2002) and they stated that drip irrigation system enhanced growth, yield and its components more than sprinkler irrigation. Organic fertilizers replinshment the soil by nutrients and improved soil properties especially when used annually. Many investigators indicated that the application of organic fertilizer increased the nutrient contents in the soil, their uptake and consequently increased the productivity of crops. Dahiya and Singh (1980) showed that the concentration of $P$ in the soil was 
significantly increased with increasing the level of FYM over the control. Also, Poonia et al. (1986) found that increasing the rate of farmyard manure application to calcareous soils in India increased $\mathrm{K}$ adsorption performance of soils over $\mathrm{Ca}$. Several concepts have been advanced to explain the improvement of nutrient availability as a result of the application of organic manure due to the reduction in soil pH (Radwan, 1997 and Abd El-Moez et al., 1999) or through the improvement of physical and chemical properties of the treated soils (Orlando et al., 1991; Sing et al., 1991 and Sikora and Azad 1993). Grain sorghum genotypes varied significantly in growth, yield and its components ( Abo-Elwafa et al.,2005).

The objective of this study was to investigate the response of two grain sorghum genotypes to new systems of irrigation and combination between mineral and organic fertilizer.

\section{MATERIALS AND METHODS}

This work was carried out at El-Wadi El-Assiuty farm, Faculty of Agriculture, Assiut University in 2003 and 2004 seasons to study the response of two grain sorghum cultivars to new systems of irrigation and farmyard manure and mineral fertilizers application to a sandy calcareous soil. Each season contain two experiments. One subjected to Drip irrigation and the other to Sprinkler one. Each experiment contained two Variables in Split plot design with three replications. The grain sorghum genotypes (Dorado and Shandawil 6) were assigned to main plots and the sub-plots were allocated to the fertilizers combinations as follows:

$\mathrm{F} 1$ = without farmyard manure $+190 \mathrm{~kg} \mathrm{~N} / \mathrm{ha}$

$\mathrm{F} 2=1.5$ ton farmyard manure $+160 \mathrm{~kg} \mathrm{~N} / \mathrm{ha}$

$\mathrm{F} 3=3.0$ ton farmyard manure $+130 \mathrm{kgN} / \mathrm{ha}$

$\mathrm{F} 4=4.5$ ton farmyard manure $+100 \mathrm{kgN} / \mathrm{ha}$

$\mathrm{F} 5=6.0$ ton farmyard manure $+70 \mathrm{~kg} \mathrm{~N} / \mathrm{ha}$

$\mathrm{F} 6=7.5$ ton farmyard manure $+40 \mathrm{kgN} / \mathrm{ha}$

The farmyard manure was applied and mixed with the soil tilth layer before sowing. Nitrogen fertilizer as a form of Amonum nitrate 33.5\% was used and divided into two equal doses, the first dose was applied 21dayes after planting, while the second dose was applied 30 days after the first dose application. The recommended doses of PK fertilizers i.e.75 $\mathrm{kg} \mathrm{P}_{2} \mathrm{O}_{5}$ and $100 \mathrm{~kg} \mathrm{~K} \mathrm{~K}_{2} \mathrm{O} / \mathrm{ha}$ were added to all experiments. Phosphorus and potassium fertilizers were added in the form of phosphoric acid $\left(85 \% \mathrm{P}_{2} \mathrm{O}_{5}\right)$ and potassium sulphate $\left(48 \% \mathrm{~K}_{2} \mathrm{O}\right)$ through irrigation water, (fertigation) under sprinkler and drip irrigation systems and splitted into ten times in both growing seasons. The total amount of water added through sprinkler and drip irrigation system was 5082 and $4236 \mathrm{~m} 3 /$ ha.respectively, which covered the evapotranspiration in experimental site according Ainer et.al. (1999). The experimental soil was sandy calcareous, as shown in Table (1). The moisture characteristics of experimental soil were shown in Table (2). The chemical analysis of farmyard manure was shown in Table (3) 
Table (1): Some physical and chemical proprieties of the experimental site soil.

\begin{tabular}{|ll|lc|lc|}
\hline \multicolumn{2}{|c|}{$\begin{array}{c}\text { Mechanical } \\
\text { analysis: }\end{array}$} & \multicolumn{2}{c|}{ Chemical analysis: } & \multicolumn{2}{c|}{ Available nutrients } \\
\hline Clay\% & 3.45 & $\mathrm{pH}(1: 1)$ suspension & 8.11 & $\mathrm{~N} \%$ & 0.05 \\
Silt\% & 6.40 & $\mathrm{EC}(1: 1)$ extract & 0.60 & $\mathrm{P}(\mathrm{ppm})$ & 3.2 \\
Sand\% & 90.15 & $\mathrm{CaCo} \%$ & 17.1 & $\mathrm{~K} \mathrm{meq} / 100 \mathrm{~g}$ soil & 0.14 \\
Texture & Sandy & OM \% & 0.25 & & \\
\hline
\end{tabular}

Table (2): Soil moisture characteristics of the experimental site.

\begin{tabular}{|l|c|c|c|c|}
\hline $\begin{array}{c}\text { Soil depth } \\
(\mathbf{c m})\end{array}$ & $\begin{array}{c}\text { Bulk density } \\
\mathbf{g} / \mathbf{c m}^{\mathbf{3}}\end{array}$ & $\begin{array}{c}\text { Field } \\
\text { capacity \% }\end{array}$ & $\begin{array}{c}\text { Permanent } \\
\text { wilting point } \%\end{array}$ & $\begin{array}{c}\text { Available water } \\
\%\end{array}$ \\
\hline $0-15$ & 1.60 & 9.3 & 3.5 & 5.8 \\
$15-30$ & 1.58 & 9.7 & 3.6 & 6.0 \\
$30-45$ & 1.53 & 9.5 & 4.0 & 5.5 \\
$45-60$ & 1.51 & 10.1 & 4.1 & 6.0 \\
\hline
\end{tabular}

Table (3): Chemical analysis of farmyard manure fertilizer (FYM)

$\begin{array}{ll}\text { pH }(1: 1) \text { suspension) } & 7.45 \\ \text { E.C. (1:1) extract) } & 6.35 \\ \text { Total } \mathrm{N} \% & 2.5 \\ \text { Total } \% \% & 0.42 \\ \text { Total K\% } & 1.25 \\ \text { O.M. \% } & 23.4 \\ \text { C/N ratio } & 18.1\end{array}$

The sub-plots area was $10.5 \mathrm{~m}^{2}$. Sorghum grains were sown in 25 and 27 of May 2003 and 2004 seasons, respectively. Sown was done in drills $50 \mathrm{~cm}$ apart and $20 \mathrm{~cm}$ within hills. Plants were thinned to secure two plants /hill. At harvest, ten guarded plants were taken at random for each plot and the following measurements were recorded: plant height $(\mathrm{cm})$, panicle length $(\mathrm{cm})$, Panicle width $(\mathrm{cm})$, panicle weight $(\mathrm{g})$ and grain yield per plant $(\mathrm{g})$. 1000 -grain weight $(\mathrm{g})$ and grain yield in $\mathrm{kg} / \mathrm{ha}$ were estimated from each plot yield basis. Protein content was estimated using micro-Kjeldahl apparatus according to A.O.A.C.(1995). Water use efficiency (WUE) as seed yield in $\mathrm{kg}$ per ha/evapotranspiration in $\mathrm{m}^{3}$ calculating by using the formula as described by Beeg and Turner (1976).

Each experiment was subjected to analysis of variance as described by Gomez and Gomez (1984). Bartletts test of variance homogeneity was carried out before the combined analysis of irrigation system according to Snedecor and Cochran (1980) to reveal the effect of this variable and their interactions involved. Means were compared using L.S.D. at $5 \%$ level.

\section{RESULTS AND DISCUSSIONS}

\section{Vegetative growth traits}

Data in Tables 4 to 7 showed that plant height,panicle length, width and weight were significantly affected by irrigation system in both seasons.Drip irrigation significantly increased plant height by 8.7 and 7.3 , 
panicle length by 19.2 and 15.8 , panicle width by 8.19 and 7.8 and panicle weight by 9.4 and $8.8 \%$ over sprinkler irrigation in 2003 and 2004 sa easons, respectively.These trends could be ascribed to that holding of soil moisture content in the root zone, which tended to be higher in the case of drip irrigation as mentioned by Cho and Yamamoto (1973). This in turn, encouraged the growth of grain sorghum by using drip irrigation system. Similar trend were obtained by Ali Osman (2001) on Sunflower and Ali (2002) on Canola.The results revealed also that fertilizers treatments had a significant effect on previous traits in both seasons. F6 treatment enhanced plant height by 34.6 and 32.4 , panicle length by 57.7 and 60.1 , panicle width by 37.0 and 37.5 and panicle weight by 31.5 and $29.2 \%$ over $\mathrm{F} 1$ treatment in 2003 and 2004 seasons, respectively. The previous obtained may be due to the increases in N, P and $\mathrm{K}$ uptake by grain sorghum. The increase in nutrient uptake may be due to the highly content of these nutrients in organic fertilizers as compared with untreated soils (Ahmed, 1997 and ElEmam,1999) or the improvement of soil structure which reflected on water movement and decreasing nutrient losses by leaching and deep percolation ( Metwally and Abdel-Bary,1999). Similar results were recorded by Ahmed and Ali (2005). Regarding to the effect of sorghum genotypes, the data showed that grain sorghum genotypes exerted a highly significant influence on plant height, panicle length, width and weight in both seasons. Shandawil 6 genotype produced the highest values of previous traits as compared with Dorado one. These may be due to genotypic behavior combination with environmental factor which may be suitable for Shandawil 6 genotype more than Dorado one. These results are in a good line with those obtained by Abo-Elwafa et al. (2005).

The interaction between irrigation system and fertilizers had a significant effect on plant height in the two growing seasons. The illustrated data in Table 4 revealed that the highest value of plant height was recorded by $F 6$ treatment when subjected to drip irrigation system. Here to, the first order interaction of irrigation system $\mathrm{x}$ genotypes affected significantly on plant height, panicle weight in the two growing seasons and panicle width in the second season only. Sandawil 6 genotype recorded the highest values of these traits when subjected to drip irrigation system (Tables 4, 6 and 7). Furthermore, the interaction between farmyard manure $\mathrm{x}$ genotypes had a significant influence on Plant height, panicle length, width and panicle weight in both seasons of study. The presented data in Tables 4 to 7 showed that the highest values of previous traits were recorded by Shandawil 6 genotype with the application of F6 treatment. Here to, the second order interaction of irrigation system $x$ farmyard manure $x$ genotypes had a significant effect on plant height in the two growing seasons. Data in Table 4 showed that the tallest plants were recorded to Shandawil 6 genotype fertilized with F6 treatment under drip irrigation system.

\section{Grain yield and yield components}

Data in Tables 8 to 10 revealed that 1000-grain weight, grain yield per plant and grain yield per ha were significantly affected by irrigation systems studied in both seasons. 
J. Agric. Sci. Mansoura Univ., 32 (7), July, 2007

4

5087 
Ali, E.A.

5

5088 
J. Agric. Sci. Mansoura Univ., 32 (7), July, 2007

6

5089 
Ali, E.A.

7

5090 
J. Agric. Sci. Mansoura Univ., 32 (7), July, 2007

8

5091 
Ali, E.A.

9

5092 
J. Agric. Sci. Mansoura Univ., 32 (7), July, 2007

10

5093 
Drip irrigation system significantly enhanced 100 -grain weight by 7.2 and 8.6 , grain yield per plant by 12.6 and 12.2 and grain yield per ha by 32.0 and $30.0 \%$ over sprinkler one in 2003 and 2004 seasons, respectively. Such increase in grain yield per ha may be due to the increase in grain weight per plant and 1000-grain weight, induced by drip irrigation system. The obtained results are in harmony with those recorded by Osman (2001) on Sunflower and Ali (2002) on Canola. Illustrated data in Tables 8 to 11 revealed that fertilizers treatments had a significant effect on 1000-grain weight, grain yield per plant and grain yield per ha. The highest values of previous traits were recorded by F6 treatment. The previous obtained may be due to the increases in N, P and K uptake by grain sorghum and improved soil physical properties which led to produced heavier grains and consequently increased grain yield per ha. Similar result obtained by (Blaise et al., 2003; Ahmed and Ali, 2005 and Bayu et al., 2006). Also, the data denoted that grain sorghum genotypes exerted a highly significant influence on previous traits. Shandawil 6 genotype produced the highest values in this respect. This is to be expected since Shandawil 6 genotype surpassed Dorado one in panicle weight, 1000- grain weight and grain yield per plant, this in turn, increase grain yield per ha. Similar trend regarding yield component was obtained by Abo-Elwafa et al. (2005).

The first order interaction of irrigation system $\mathrm{x}$ genotypes affected significantly on grain yield per plant and grain yield per ha in the two growing seasons. Shandawil 6 genotype recorded the highest values of these traits when subjected to drip irrigation system (Tables 9 and 11). Furthermore, the interaction between fertilizers and genotypes had a significant influence on 1000 -grain weight, grain yield per plant and grain yield per ha in the two growing seasons. The presented data in Tables 8, 9 and 11 showed that the highest values of previous traits were recorded by Shandawil 6 genotype fertilized by F6 fertilizer treatment. Also, the second order interaction of irrigation system $x$ fertilizers $x$ genotypes had a significant influences on grain yield per plant and ha in the two growing seasons. Data in Tables 9 and 11 explained that the highest values of previous traits were recorded by Shndawil 6 genotype supplemented with F6 fertilizers treatment and irrigated by drip irrigation system.

\section{Grain sorghum protein content}

Data exhibited in table (11) denoted that irrigation systems had a significant effect on grain sorghum protein content in both seasons of study. In this respect sprinkler irrigation system surpassed drip one by 6.4 and $6.9 \%$ in 2003 and 2004 seasons, respectively. This is may be due to some water stress makes by sprinkler irrigation system which caused some reduction in sorghum grain size and consequently increased grain protein content. Similar result obtained by Ali (2002). Fertilizers treatments had a significant effect on grain protein content in the tow growing seasons. F6 treatment gained the highest values of grain protein content as compared with the others treatments. 
J. Agric. Sci. Mansoura Univ., 32 (7), July, 2007

5095 
Ali, E.A.

The previous obtained may be due to the increases in $\mathrm{N}$ uptake by grain sorghum which led to increased amino acids content and consequently increased grain protein content. The previous obtained are in a good line with that obtained by Bayu et al (2006).

The first order interactions of irrigation system $x$ genotypes and irrigation systems $x$ fertilizers treatments had a significant effect in this respect in both seasons. The highest values of grain protein content were obtained by F6 fertilizers treatment irrigated by sprinkler irrigation and Shandawil 6 genotype subjected to sprinkler irrigation, respectively.

\section{Water use efficiency}

Exhibited data in Table (12) focused that irrigation systems studied significantly affected water use efficiency in favor of drip irrigation one in the two growing seasons. This is logic since drip irrigation out yielded seed yield / ha and used less amount of irrigation water. These in turn, increased water use efficiency in favor of drip irrigation as compared with sprinkler one. These results are confirmed with those obtained by Osman (2000) on sunflower and Ali(2002) on canola. Also the data denoted that water use efficiency reacted significantly to grain sorghum genotype in both seasons . Shandawil 6 genotype superior on Dorado one in this respect. This is expected since shandawil 6 gained the highest values of grain yield / ha which led to the previous result. Here too, the data showed that water use efficiency reacted significantly tofertilizers treatments in both seasons. F 6 treatment gained the highest values in this respect as compared with the others treatments. Thisis may due to the improvement of soil structure by farmyard manure in the treated soils which reflected on water movement and decreasing nutrients lossesby leaching and deep percolation (Metwaly and Abdel-Bary, 1999). This is logic since F6 treatment surpassed others treatments in grain yield / ha and consequently led to the previous result.

The first order interactions of irrigation $x$ genotypes, irrigation $x$ fertilization and fertilization $x$ genotypes had a significant effect in this respect in both seasons. The highest values of water use efficiency were recorded by F6 fertilizers treatments subjected to drip irrigation, Shandawil 6 genotype subjected to drip irrigation and shandawil6 genotype subjected to F6 fertilizers treatments, respectively. 
J. Agric. Sci. Mansoura Univ., 32 (7), July, 2007

12

5097 
Ali, E.A.

\section{Conclusion}

The obtained results indicated that drip irrigation system surpassed sprinkler one in the most tested traits. Shandawil 6 genotype gained the highest values of all tested traits except grain protein content. 7.5 ton farmyard manure $+80 \mathrm{~kg} \mathrm{~N} / \mathrm{ha}$ treatment exhibited a highly significant effect in all studied traits in the two growing seasons. So the investigator recommended to planting Shandawil 6 genotype under drip irrigation system fertilized by 7.5 ton farmyard manure $+40 \mathrm{~kg} \mathrm{~N} /$ ha.

\section{REFERENCES}

Abd El-Moez, M.R., A.L. Salah and A.H. Wanas (1999). Influence of some organic composts on yield, nutrients uptake and consumptive use of fennel and coriander plants and some soil physical properties. J. Agric. Sci. Mansoura Univ., 24 (10): 6237-6253.

Abo-Elwafa, A., T.A. Ahmed, E.A. Hassaballa and M.A. Sayed (2005). Heterosis and line $X$ tester analysis of combining ability in grain sorghum [Sorghum bicolor (L.) Moench]. Assiut Journal of Agricultural Science 36:159-175.

Ahmed, M.M.M. (1997). Utilization of certain sugar industry wastes for fertilization of some crops. M.Sc. Thesis, Fac. Agric., Assiut Univ., Egypt.

Ahmed, M.M.M and E.A. Ali (2005). Effect of different sources of organic fertilizers on the accumulation and movement of NPK in sandy calcareous soilsandthe productivity of wheat and grain sorghum. Assiut J. Agric.Sci.Vol.36,No3.

Ahmed, M.M.M and E. B. A. Osman (2003). Response of peanut plants grown on a sandy calcareous soil to fertilization with farmyard manure and a mixture of sugar cane wastes. Assiut J. of Agric. Sci. Vol. (34), No.6

Ainer, N.G., W.I.Miseha, F.A.Abbas and H.M.Eid (1999).A New Concept of Rationalization of Irrigation Water Use in Egypt. Third Conf.of On-Farm Irrigation and Agro climatology. January 25-27, Egypt.

Ali, E.A. (2002). Response of some canola varieties to modern systems of irrigation and fertilization on the newly reclaimed soil. ph. D. Agron. Dept., Fac. of Agric. Assuit Univ., Egyp.

A.O.A.C.(1995). Association of Official Analytical Chemists. Official methods of analysis, 16 th Ed.AOAC International, Washington, D.C., USA.

Bayu W., N. F. G. Rethman, P. S. Hammes and G. Alemu(2006 ). Effects of farmyard manure and inorganic fertilizers on Sorghum growth, yield, and nitrogen use in a Semi-Arid Area of Ethiopia. Journal of Plant Nutration, Volume rq, Issue 2 February 2006 , pages $391-407$.

Begg,J.F. and N.C.Turner (1976). Crop water deficits. Advances in Agron. Vol.28pp.189.

Blaise, D.; J. V. Singh; M. V. Venugopalan and C. D. Mayee (2003). Effect of continuous application of manures and fertilizers on productivity of cotton-sorghum rotation. Acta agronomica hungarica, vol. 51, n¹, pp. 61-67.

Cho, I. and Yamamoto (1973). On application efficiency and effects of trickle irrigation in a sand field. Bulletin No.12, 20-28

Dahiya, S.S and R. Singh. (1980). Effect of Farmyard manure and $\mathrm{CaCO} 3$ on dry matter yield and nutrient uptake by oats (Avena sativa). Plant and Soil, 56:391-402. 
El- Emam, M.A.A.E. (1999). Studies on nutrients availability from plant residues and different organic fertilizers. M. Sc. Thesis, Fac. Agric., Zagazig Univ., (Benha Branch) Egypt.

Gomez, K.A. and Gomez, A.A. (1984). Statistical procedures for Agriculture research. A Wiley-Inter Scince Publication, John Wiley and sons, Inc. New York, USA.

Metwally Sh.M. and E.A Abdel-Bary (1999). Assessment of application of amendments to sandy soils using a computer model. Zagazig J. Agric. Res. Vol. No. (2).

Orlando Filho, J.L.S.F and A.A Rodella (1991). Effects of filter cake applications on sugar yield in Brazil. Sugar J.54 (3):22-24.

Osman, E.B. A.( 2001). Productivity of some sunflower hybrids by using modern systems of irrigation and fertilization under newly reclaimed soil. ph.D.Agron. Dept.,Fac. Agric. Assiut Univ., Egypt.

Poonia, S.R., S.C. Mehta and R. Pal. (1986). Exchange equilibrium of potassium in soils: 1 - Effect of Farmyard manure on potassium-calcium exchange. Soil Sci. 14(1): 77-83.

Radwan, S.A (1997). Changes in some chemical forms of phosphorus as affected by some soil amendments in calcareous soil. Egypt J. Appl. Sci. 12(12).

Sikora, L.J and M.J Asad (1993). Effect of compost fertilizer combinations on wheat yields. Compost Sci. and Utilization (2):93-96.

Sing, G., O.P. Sing, R.S. Sing, R.A. Yadav and B. Sing (1991). Effect of press mud and fertilizer application on yield and quality of cane in flood affected condition. Bharatiya Sugar Vol. (27):27-30

Snedecor, C.W. and Cochran, W.C. (1980). Statistical Methods. 7 th Ed.lowa state Univ.Press, Ames, lowa.

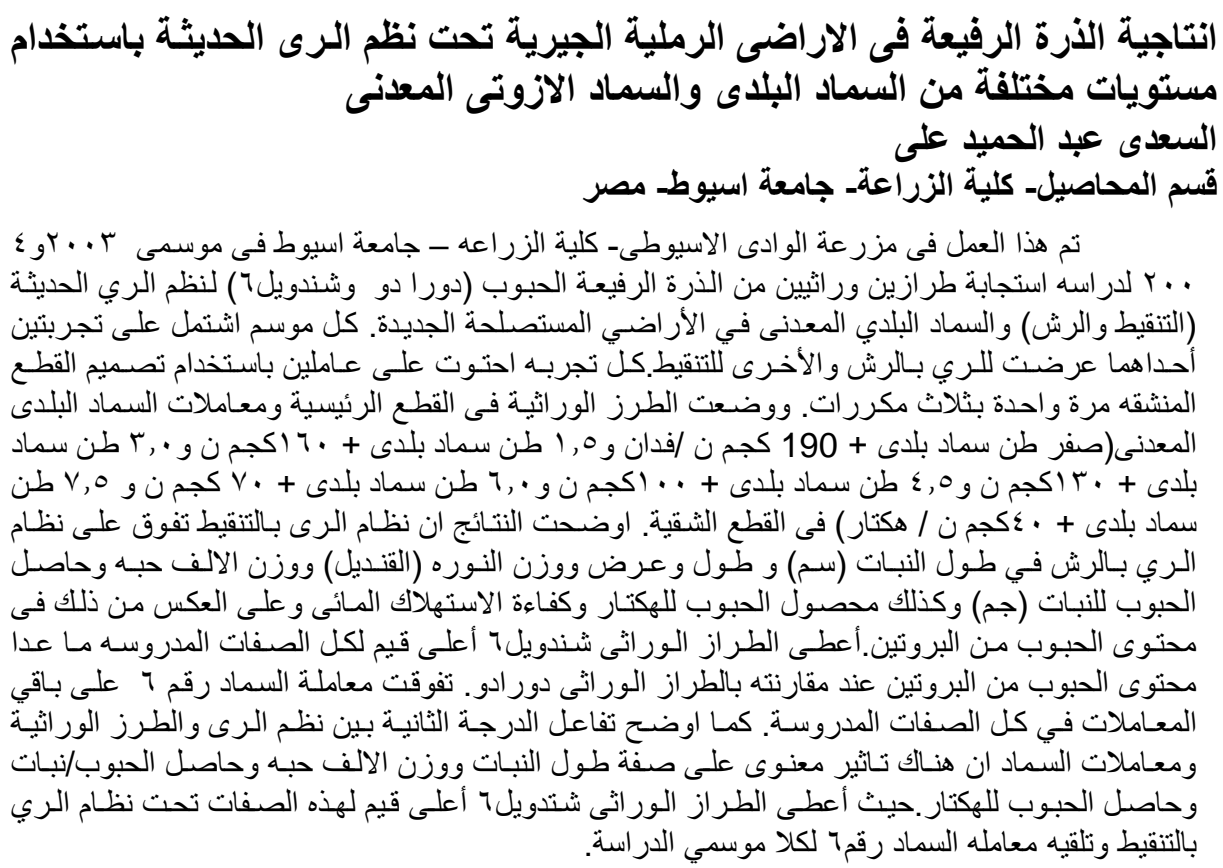


Table (4): Effect of Irriation system, Genotypes, Fertilization and their interaction involved on plant height (cm) of Sorghum.

\begin{tabular}{|c|c|c|c|c|c|c|c|c|c|c|c|c|c|c|}
\hline Seasons & \multicolumn{7}{|c|}{2003} & \multicolumn{7}{|c|}{2004} \\
\hline \multirow{2}{*}{\begin{tabular}{|c|} 
Irrigation \\
Genotypes \\
Fertilization \\
\end{tabular}} & \multicolumn{2}{|r|}{ Drip } & \multicolumn{3}{|c|}{ Sprinkler } & \multicolumn{2}{|c|}{ FxV } & \multicolumn{2}{|r|}{ Drip } & \multicolumn{3}{|c|}{ Sprinkler } & \multicolumn{2}{|c|}{ FxV } \\
\hline & V1 & V2 & V1 & V2 & Mean $\begin{array}{c}\text { G. } \\
\text { Mean }\end{array}$ & V1 & V2 & V1 & V2 1 Mean & V1 & V2 & Mean $\begin{array}{c}\text { G. } \\
\text { Mean }\end{array}$ & V1 & V2 \\
\hline $\begin{array}{ll}\mathrm{F} 1 \\
\end{array}$ & 115.4 & $133.6 \mid 124.5$ & 106.4 & 120.0 & $\mid 113.2118 .9$ & 110. & 126.8 & 118.7 & 136.7127 .7 & 112.7 & 123.7 & \begin{tabular}{|l|l|}
118.2 & 122.9 \\
\end{tabular} & 115.7 & 130.2 \\
\hline $\mathrm{F} 1$ & 121.7 & 134.8 128.3 & 114.4 & 127.3 & 120.9124 .6 & 118. & 131. & 123.7 & $137.7 \mid 130.7$ & 117.7 & 131.7 & 724.7127 .7 & 120.7 & 134.7 \\
\hline F3 & 127.2 & $140.3 \mid 133.8$ & 119.4 & 133.8 & $|126.6| 130.2$ & 123.3 & 137. & 130.0 & 143.3136 .7 & 122.7 & 136.7 & 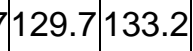 & 126.3 & 140.0 \\
\hline $\mathrm{F} 4$ & 143.8 & 165.4 & 139.2 & 155.0 & 147.1150 .9 & 141.5 & 160.2 & 148.1 & 169.0158 .5 & 142.3 & 157.3 & \begin{tabular}{lll|}
149.8 & 154.2 \\
\end{tabular} & 145.2 & 163.2 \\
\hline F5 & 147.0 & $176.7 \mid 161.9$ & 140.1 & 138.1 & 139.1150 .5 & 143.6 & 157.4 & 150.3 & 177.7164 .0 & 142.7 & 145.3 & 144.0154 .0 & 146.5 & 161.5 \\
\hline F6 & 151.3 & 177.5164 .4 & 142.3 & 169..3 & 3155.8160 .1 & $146 . \varepsilon$ & 173.4 & 155.0 & 180.3167 .7 & 145.0 & 171.0 & 158.0162 .8 & 150.0 & 175.7 \\
\hline \begin{tabular}{|l|} 
Mean \\
\end{tabular} & 134.4 & \begin{tabular}{|l|l|}
154.7 & 144.6 \\
\end{tabular} & 126.9 & 140.6 & 133.8139 .2 & 130.7 & 147.7 & 137.6 & 157.4147 .5 & 130.5 & 144.3 & \begin{tabular}{|l|l|l|}
337.4 & 142.5 \\
\end{tabular} & 134.1 & 150.9 \\
\hline L.S.D.0.05 for $\mathrm{F}$ & & & & 2.45 & & & & & & & 2.45 & & & \\
\hline L.S.D.0.05 I X V & & & & 5.17 & & & & & & & 3.13 & & & \\
\hline L.S.D.0.05 IX F & & & & 3.46 & & & & & & & 5.17 & & & \\
\hline L.S.D.0.05 F X v & & & & 3.46 & & & & & & & 4.43 & & & \\
\hline $\begin{array}{l}\text { L.S.D.0.05 I X F } \\
X_{V}\end{array}$ & & & & 4.89 & & & & & & & 4.43 & & & \\
\hline
\end{tabular}

I means Irrigation

V1,V2means Dorado and Shandawil 6 genotypes, respectively

$\mathrm{F} 1=0.0$ farmyard manure $+190 \mathrm{~kg} \mathrm{~N} / \mathrm{ha}$

$F 2=1.5$ ton farmyard manure $+160 \mathrm{~kg} \mathrm{~N} / \mathrm{ha}$

$\mathrm{F} 3=3.0$ ton farmyard manure $+130 \mathrm{kgN} / \mathrm{ha}$

$\mathrm{F} 4=4.5$ ton farmyard manure $+100 \mathrm{kgN} / \mathrm{ha}$

$\mathrm{F} 5=6.0$ ton farmyard manure $+70 \mathrm{~kg} \mathrm{~N} / \mathrm{ha}$

$\mathrm{F} 6=7.5$ ton farmyard manure $+40 \mathrm{kgN} / \mathrm{ha}$ 
Table ( 5 ): Effect of Irriation system, Genotypes, Fertilization and their interaction involved on panicle length in $\mathrm{cm}$ of Sorghum.

\begin{tabular}{|c|c|c|c|c|c|c|c|c|c|c|c|c|c|c|c|c|}
\hline Seasons & \multicolumn{8}{|c|}{2003} & \multicolumn{8}{|c|}{2004} \\
\hline Irrigation & \multicolumn{2}{|r|}{ Drip } & \multicolumn{4}{|c|}{ Sprinkler } & \multicolumn{2}{|c|}{ FxV } & \multicolumn{3}{|c|}{ Drip } & \multicolumn{3}{|c|}{ Sprinkler } & \multicolumn{2}{|c|}{ FxV } \\
\hline $\begin{array}{l}\text { Genotypes } \\
\text { Fertilization }\end{array}$ & V1 & \begin{tabular}{l|l|} 
V2 & Mean \\
\end{tabular} & V1 & V2 & Mean & G. Mean & V1 & V2 & V1 & V2 & Mean & V1 & V2 Mean & G. Mean & V1 & V2 \\
\hline $\begin{array}{ll}\mathrm{F} 1 \\
\end{array}$ & 18.3 & \begin{tabular}{|l|l|}
23.2 & 20.8 \\
\end{tabular} & 16.3 & 19.9 & 18.1 & 19.4 & 17.3 & 21.6 & 20.8 & 25.2 & 23.0 & 17.3 & \begin{tabular}{|l|l|}
21.3 & 19.3 \\
\end{tabular} & 21.1 & 19.0 & 23.3 \\
\hline F1 & 22.4 & 25.423 .9 & 17.4 & 20.6 & 19.0 & 21.5 & 19.9 & 23.0 & 24.7 & 26.8 & 25.8 & 19.6 & \begin{tabular}{|l|l|}
22.6 & 21.1
\end{tabular} & 23.4 & 22.1 & 24.7 \\
\hline F3 & 20.7 & 28.024 .4 & 15.7 & 22.7 & 19.2 & 21.8 & 18.2 & 25.4 & 23.5 & 30.0 & 26.8 & 18.0 & 24.821 .4 & 24.1 & 20.8 & 27.4 \\
\hline $\mathrm{F} 4$ & 24.5 & 33.529 .0 & 20.8 & 28.4 & 24.6 & 26.8 & 22.7 & 30.9 & 26.2 & 34.6 & 30.4 & 23.5 & 30.827 .2 & 28.8 & 24.8 & 32.7 \\
\hline F5 & 28.0 & \begin{tabular}{ll|l}
37.5 & 32.7
\end{tabular} & 24.9 & 29.4 & 27.2 & 29.9 & 26.5 & 33.4 & 30.0 & 38.0 & 34.0 & 26.4 & 33.229 .8 & 31.9 & 28.2 & 35.6 \\
\hline F6 & 28.3 & 36.932 .6 & 25.2 & 31.8 & 28.5 & 30.6 & 26.8 & 34.4 & 31.1 & 39.1 & 35.1 & 27.1 & 37.932 .5 & 33.8 & 29.1 & 38.5 \\
\hline Mean & 23.7 & \begin{tabular}{|l|l|}
30.8 & 27.2 \\
\end{tabular} & 280.1 & 25.5 & 22.8 & 25.0 & 21.9 & 28.1 & 26.0 & 32.3 & 29.2 & 21.9 & 28.425 .2 & 27.15 & 24.0 & 30.4 \\
\hline L.S.D. 0.05 for $F$ & & & & 1.4 & & & & & & & & & 1.14 & & & \\
\hline \begin{tabular}{|l|l} 
L.S.D.0.05 I X V \\
\end{tabular} & & & & NS & & & & & & & & & NS & & & \\
\hline L.S.D.0.05 IX F & & & & $\mathrm{NS}$ & & & & & & & & & NS & & & \\
\hline L.S.D.0.05 F X v & & & & 1.6 & & & & & & & & & 2.07 & & & \\
\hline L.S.D.0.05 , X F Xv & & & & $\mathrm{NS}$ & & & & & & & & & NS & & & \\
\hline
\end{tabular}


Table (6): Effect of Irriation system, Genotypes, Fertilization and their interaction involved on panicle wids (cm) of Sorghum.

\begin{tabular}{|c|c|c|c|c|c|c|c|c|c|c|c|c|c|c|c|c|c|c|}
\hline Seasons & \multicolumn{9}{|c|}{2003} & \multicolumn{9}{|c|}{2004} \\
\hline Irrigation & \multicolumn{3}{|c|}{ Drip } & \multicolumn{4}{|c|}{ Sprinkler } & \multicolumn{2}{|c|}{ FxV } & \multicolumn{3}{|c|}{ Drip } & \multicolumn{4}{|c|}{ Sprinkler } & \multicolumn{2}{|c|}{ FxV } \\
\hline $\begin{array}{l}\text { Genotypes } \\
\text { Fertilization }\end{array}$ & V1 & V2 & Mean & V1 & V2 & Mean & G. Mean & V1 & V2 & V1 & $\mathbf{V 2}$ & Mean & V1 & V2 & Mean & G. Mean & V1 & V2 \\
\hline $\mathrm{F} 1$ & 5.2 & 6.0 & 5.6 & 4.7 & 5.5 & 5.1 & 5.4 & 4.9 & 5.8 & 5.4 & 6.3 & 5.9 & 5.1 & 5.7 & 5.4 & 5.6 & 5.3 & 6.0 \\
\hline $\mathrm{F} 1$ & 5.5 & 6.1 & 5.8 & 4.9 & 5.7 & 5.3 & 5.6 & 5.2 & 5.9 & 5.8 & 6.5 & 6.2 & 5.3 & 5.9 & 5.6 & 5.9 & 5.6 & 6.2 \\
\hline F3 & 5.7 & 6.4 & 6.1 & 5.1 & 5.8 & 5.4 & 5.7 & 5.4 & 6.1 & 5.9 & 6.7 & 6.4 & 5.4 & 5.9 & 5.7 & 6.0 & 5.7 & 6.4 \\
\hline F4 & 6.2 & 8.2 & 7.2 & 5.5 & 7.7 & 6.6 & 6.9 & 5.9 & 7.9 & 6.4 & 8.4 & 7.4 & 5.8 & 8.2 & 7.0 & 7.2 & 6.1 & 8.3 \\
\hline F5 & 6.7 & 8.5 & 7.6 & 6.0 & 7.6 & 6.8 & 7.2 & 6.4 & 8.1 & 7.1 & 8.8 & 7.9 & 6.4 & 8.0 & 7.2 & 7.6 & 6.8 & 8.4 \\
\hline F6 & 6.8 & 8.6 & 7.7 & 5.9 & 8.1 & 7.1 & 7.4 & 6.4 & 8.4 & 7.1 & 8.9 & 7.9 & 6.3 & 8.4 & 7.4 & 7.7 & 6.7 & 8.6 \\
\hline Mean & 6.0 & 7.3 & 6.6 & 5.4 & 6.8 & 6.1 & 6.4 & 5.7 & 7.0 & 6.3 & 7.6 & 6.9 & 5.7 & 7.0 & 6.4 & 6.7 & 6.0 & 7.3 \\
\hline L.S.D. 0.05 for $F$ & \multicolumn{9}{|c|}{0.17} & \multicolumn{9}{|c|}{0.20} \\
\hline L.S.D.0.05 I X V & \multicolumn{9}{|c|}{ NS } & \multicolumn{9}{|c|}{ NS } \\
\hline L.S.D.0.05 IX F & \multicolumn{9}{|c|}{ NS } & \multicolumn{9}{|c|}{ NS } \\
\hline L.S.D. $0.05 \mathrm{~F} \mathrm{X} \mathrm{V}$ & \multicolumn{9}{|c|}{0.24} & \multicolumn{9}{|c|}{0.92} \\
\hline L.S.D.0.05 । X F X V & \multicolumn{9}{|c|}{ NS } & \multicolumn{9}{|c|}{ NS } \\
\hline
\end{tabular}


Table ( 7 ): Effect of Irriation system Genotypes, Fertilization and their interaction involved on panicle weight (g) of Sorghum.

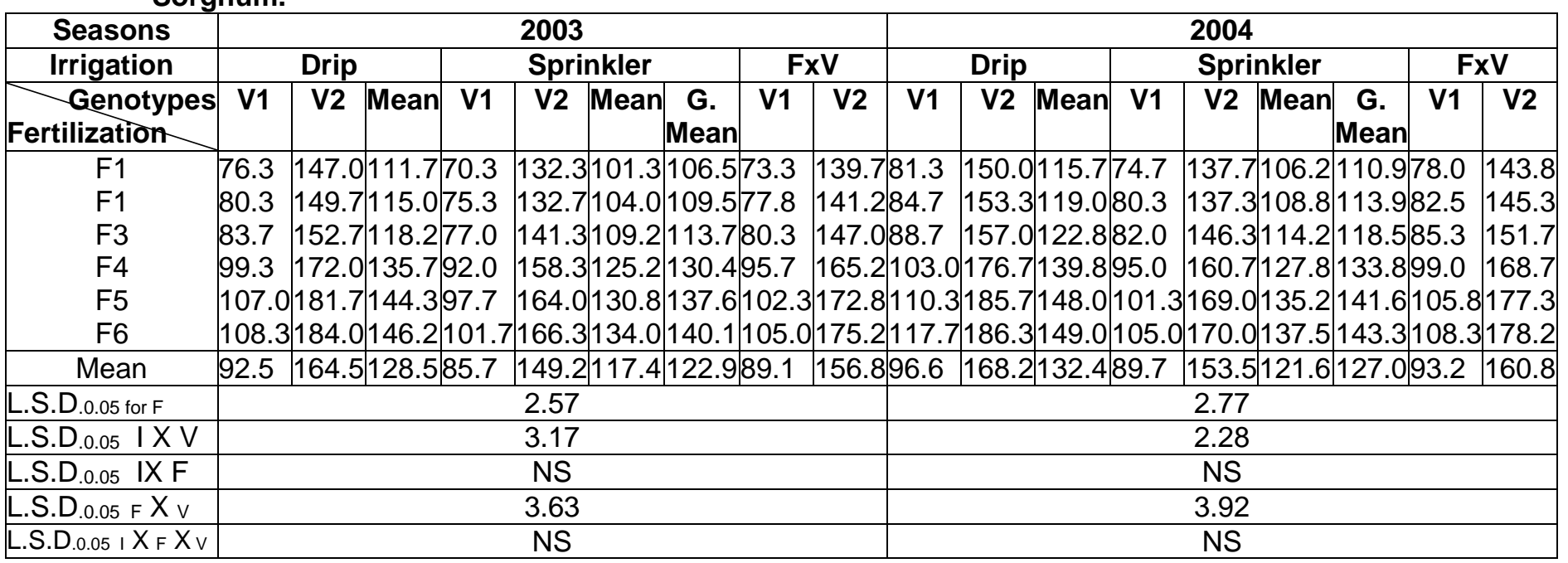


Table (8): Effect of Irriation system, Genotypes, Fertilization and their interaction involved on 1000-seed weight (g) of Sorghum.

\begin{tabular}{|c|c|c|c|c|c|c|c|c|c|c|c|c|c|c|c|c|c|}
\hline \multirow{3}{*}{\begin{tabular}{|c|} 
Seasons \\
Irrigation \\
Genotypes \\
Fertilization \\
\end{tabular}} & \multicolumn{8}{|c|}{2003} & \multicolumn{9}{|c|}{2004} \\
\hline & \multicolumn{2}{|r|}{ Drip } & \multicolumn{4}{|c|}{ Sprinkler } & \multicolumn{2}{|c|}{ FxV } & \multicolumn{3}{|c|}{ Drip } & \multicolumn{4}{|c|}{ Sprinkler } & \multicolumn{2}{|c|}{ FxV } \\
\hline & V1 & V2 Mean & V1 & V2 & Mean & G. Mean & V1 & V2 & V1 & V2 & Mean & V1 & V2 & Mean & G. Mean & V1 & V2 \\
\hline $\mathrm{F} 1$ & 23.3 & 26.024 .7 & 21.2 & 24.2 & 22.7 & 23.7 & 22.3 & 25.1 & 23.8 & 27.0 & 25.4 & 21.7 & 23.7 & 22.7 & 24.0 & 22.8 & 25.3 \\
\hline F1 & 23.8 & 26.725 .3 & 22.5 & 24.7 & 23.6 & 24.4 & 23.2 & 25.7 & 24.8 & 27.3 & 26.1 & 22.8 & 25.0 & 23.9 & 25.0 & 23.8 & 26.2 \\
\hline F3 & 24.5 & 27.025 .8 & 22.8 & 25.4 & 24.1 & 24.9 & 23.7 & 26.2 & 25.5 & 27.7 & 26.6 & 23.5 & 25.7 & 24.6 & 25.6 & 24.5 & 26.7 \\
\hline F4 & 25.3 & 30.327 .8 & 23.3 & 28.8 & 26.1 & 26.9 & 24.3 & 29.6 & 26.3 & 31.0 & 28.7 & 23.7 & 29.3 & 26.5 & 27.6 & 25.0 & 30.2 \\
\hline F5 & 26.8 & 30.728 .8 & 25.2 & 29.0 & 27.1 & 27.9 & 26.0 & 29.8 & 27.3 & 31.5 & 29.4 & 24.7 & 29.5 & 27.1 & 28.3 & 26.0 & 30.5 \\
\hline F6 & 27.0 & 31.329 .2 & 25.2 & 29.3 & 27.3 & 28.2 & 26.1 & 30.3 & 27.5 & 31.8 & 29.7 & 25.7 & 29.7 & 27.7 & 28.7 & 26.6 & 30.8 \\
\hline Mean & 25.1 & 28.726 .9 & 23.4 & 26.9 & 25.1 & 26.0 & 24.3 & 27.9 & 25.9 & 29.4 & 27.6 & 23.7 & 27.1 & 25.4 & 26.5 & 24.8 & 28.3 \\
\hline L.S.D.0.05 for $F$ & & & & & & & & & & & & & & & & & \\
\hline L.S.D.0.05 I X V & & & & & & & & & & & & & & & & & \\
\hline L.S.D.0.05 IX F & & & & & & & & & & & & & & & & & \\
\hline L.S.D.0.05 F X V & & & & & & & & & & & & & & & & & \\
\hline L.S.D.0.05 । X F X V & & & & & & & & & & & & & & & & & \\
\hline
\end{tabular}


Table (9): Effect of Irriation system, Genotypes, Fertilization and their interaction involved on grain yield/plant (g) of Sorghum.

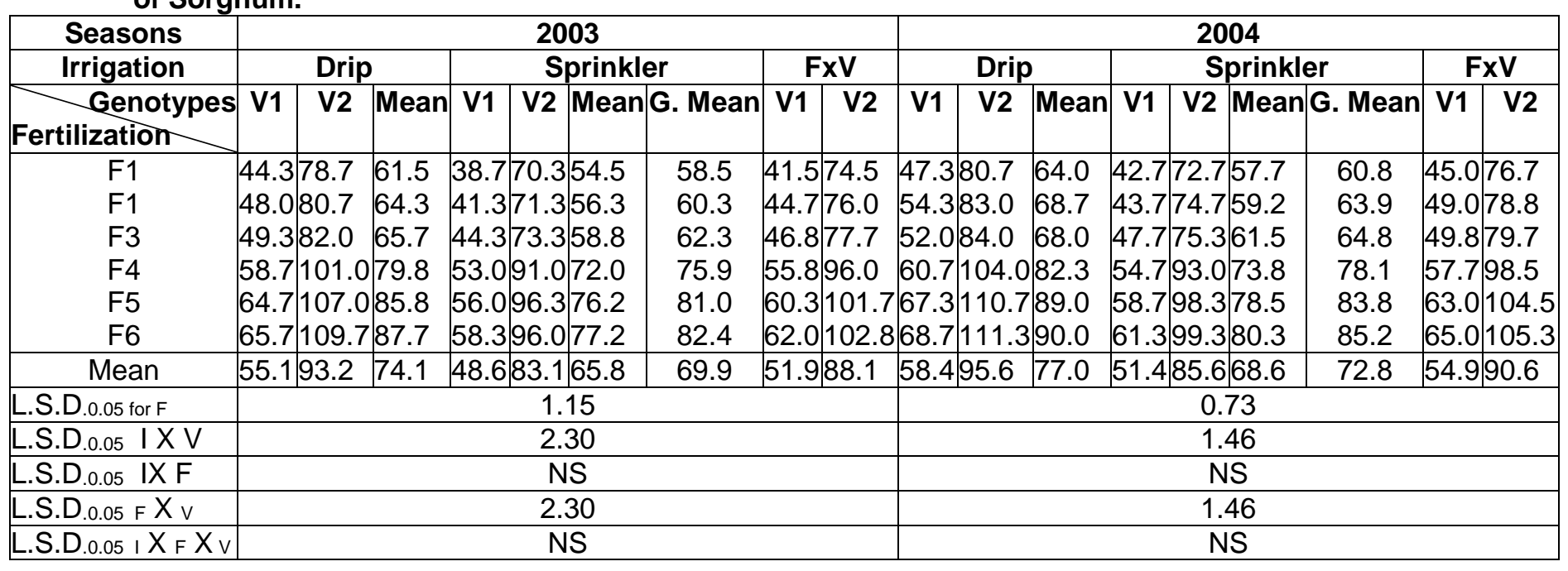


Table ( 10 ) :Effect of Irriation system ,Genotypes, Fertilization and their interaction involved on grain yield $\mathrm{kg} / \mathrm{ha}$ of Sorghum.

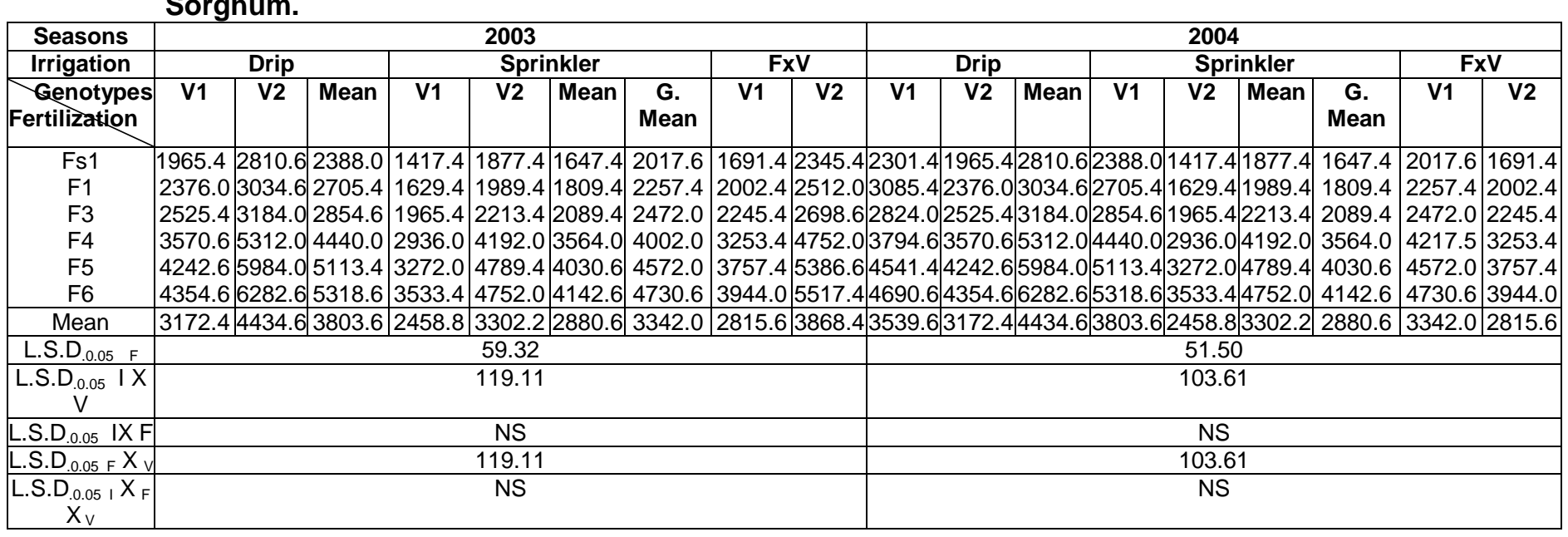


Table (11): Effect of Irriation system, Genotypes, Fertilization and their interaction involved on grain protein content of Sorghum.

\begin{tabular}{|c|c|c|c|c|c|c|c|c|c|c|c|c|c|c|c|c|}
\hline \multirow{3}{*}{\begin{tabular}{|c|} 
Seasons \\
Irrigation \\
Genotypes \\
Fertilization \\
\end{tabular}} & \multicolumn{8}{|c|}{2003} & \multicolumn{8}{|c|}{2004} \\
\hline & \multicolumn{6}{|c|}{ Sprinkler } & \multicolumn{2}{|c|}{ FxV } & \multicolumn{2}{|r|}{ Drip } & \multicolumn{4}{|c|}{ Sprinkler } & \multicolumn{2}{|c|}{ FxV } \\
\hline & V1 & \begin{tabular}{l|l|} 
V2 & Mean
\end{tabular} & V1 & V2 & Mean & $\begin{array}{c}\text { G. } \\
\text { Mean }\end{array}$ & V1 & V2 & V1 & V2 Mean & V1 & V2 & Mean & $\begin{array}{c}\text { G. } \\
\text { Mean }\end{array}$ & V1 & V2 \\
\hline $\mathrm{F} 1$ & 9.10 & \begin{tabular}{l|l|l}
9.40 & 9.25 & 9
\end{tabular} & 9.80 & 9.90 & 9.90 & 9.589 & 9.45 & 9.70 & 9.50 & \begin{tabular}{|l|l|l}
9.60 & 9.60 & 1
\end{tabular} & 10.00 & 10.10 & 10.10 & 9.85 & 9.75 & 9.85 \\
\hline $\mathrm{F} 1$ & 10.20 & 10.1010 .151 & 10.80 & 10.70 & 10.80 & 10.481 & 10.50 & 10.40 & 10.40 & $10.00|10.20| 1$ & 10.90 & 10.80 & 10.90 & 10.55 & 10.65 & 10.40 \\
\hline F3 & 8.60 & \begin{tabular}{l|l|l}
9.20 & 8.90 & 9
\end{tabular} & 9.40 & 9.60 & 9.50 & 9.209 & 9.00 & 9.40 & 9.00 & \begin{tabular}{|l|l|l}
9.40 & 9.20 & 1
\end{tabular} & 11.00 & 10.50 & 10.75 & 9.98 & 10.00 & 9.95 \\
\hline $\mathrm{F} 4$ & 10.40 & $\begin{array}{llll}8.60 & 9.50 & 1\end{array}$ & 10.90 & 10.20 & 10.60 & 10.051 & 10.70 & 9.40 & 10.20 & 9.009 .60 & 10.90 & 10.80 & 10.90 & 10.25 & 10.55 & 9.90 \\
\hline F5 & 9.80 & 10.109 .95 & 10.20 & 10.60 & 10.40 & 10.181 & 10.00 & 10.40 & 9.60 & 10.009 .80 & 9.80 & 9.90 & 9.90 & $9.85 \subseteq$ & 9.70 & 9.95 \\
\hline $\mathrm{F} 6$ & 11.50 & 11.2011 .351 & 11.70 & 11.90 & 11.80 & 11.581 & 11.60 & 11.60 & 11.30 & \begin{tabular}{|l|l|l|l|}
11.40 & 11.40 \\
\end{tabular} & 11.60 & 11.90 & 11.80 & 11.60 & 11.45 & 11.65 \\
\hline \begin{tabular}{|c|} 
Mean \\
\end{tabular} & 9.93 & \begin{tabular}{|l|l|l|}
9.77 & 9.85 & 1 \\
\end{tabular} & 10.47 & 10.48 & 10.48 & 10.171 & 10.20 & 10.13 & 10.00 & \begin{tabular}{|l|l|l|}
9.90 & 10.00 & 1 \\
\end{tabular} & 10.70 & 10.70 & 10.69 & 10.34 & 10.35 & 10.29 \\
\hline L.S.D. 0.05 for $F$ & & & & 0.10 & & & & & & & & 0.15 & & & & \\
\hline \begin{tabular}{|l|l} 
L.S.D.0.05 I X V \\
\end{tabular} & & & & 0.28 & & & & & & & & 0.40 & & & & \\
\hline L.S.D.0.05 IX F & & & & 0.20 & & & & & & & & 0.30 & & & & \\
\hline L.S.D.0.05 F X v & & & & NS & & & & & & & & NS & & & & \\
\hline L.S.D.0.05 । X F X v & & & & NS & & & & & & & & NS & & & & \\
\hline
\end{tabular}


Table (12): Effect of Irriation system, Genotypes, Fertilization and their interaction involved on water use efficiency $\left(\mathrm{kg} / \mathrm{m}^{3}\right)$ of Sorghum.

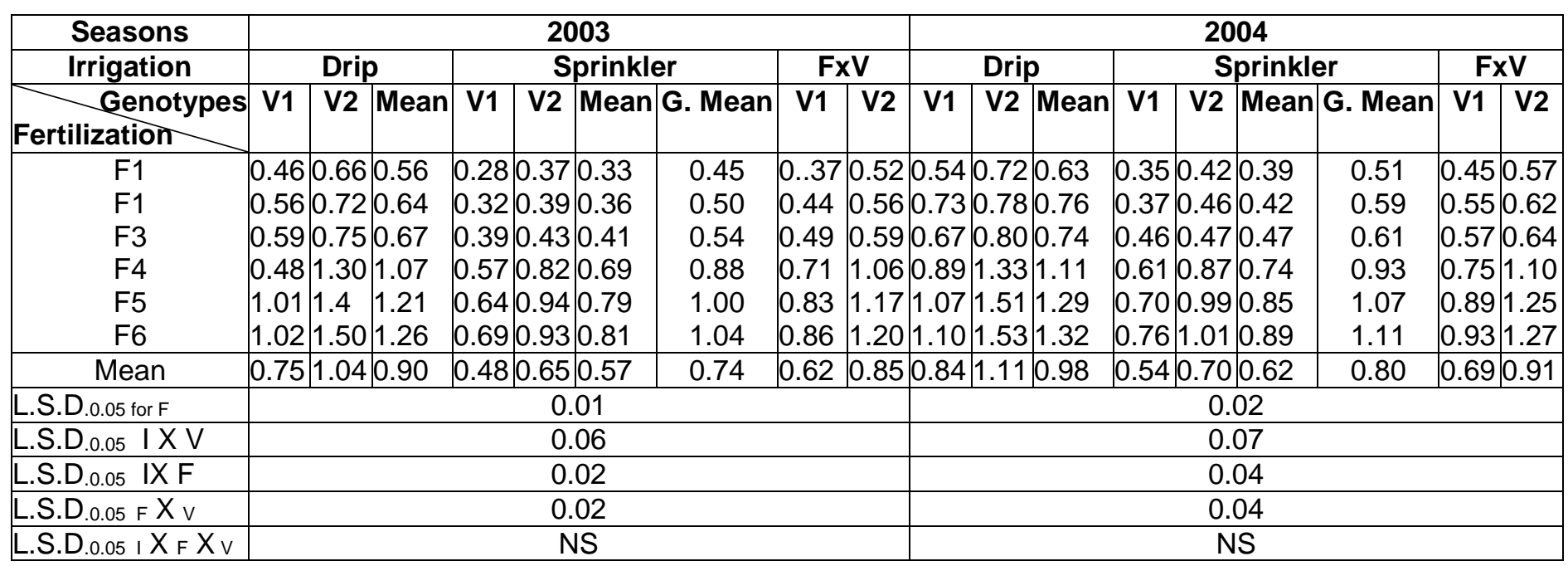

